\title{
Religions in Times of Peace: Conceptualizing the Practice of Interreligious Dialogue in the Post- Conflict Environment
}

\author{
Lailatul Fitriyah \\ University of Notre Dame
}

\begin{abstract}
The article makes the case of collaborating the notion of interreligious dialogue and the concept of the zone of peace in an attempt to provide a more practical yet effective channel of reconciliation in the context of post-interreligious violence. There are three critics implied throughout the article. First, that the current state of most of interreligious dialogue in post-conflict settings is lack of two things, namely, the inclusive structure that would allow non-scholars and non-clergies to engage in the theological dialogue, and a coherent structure for the currently diasporic efforts in interreligious dialogue. Second, that the concept of zone of peace is severely limited, particularly due to its dependence on material modalities in forging the path of reconciliation toward peace. And third, that the elusive and elitist nature of interreligious dialogue in post-conflict settings, and the limited material modalities of the zone of peace can be expanded by collaborating the two notions into an applicable zone of interreligious peace. Lastly, the paper will take the case of the village of Latta in Maluku to present a practical context for the zone of interreligious peace.
\end{abstract}

Keywords: interreligious dialogue, zone of peace, post-interreligious violence

\begin{abstract}
Abstrak
Artikel ini membahas kolaborasi antara dialog antar-agama dan konsep zona perdamaian dalam upaya menyediakan jalur rekonsiliasi yang praktis dan efektif dalam konteks pasca kekerasan antar-agama. Terdapat tiga kritik yang dikemukakan dalam artikel ini. Pertama, situasi pada kebanyakan dialog antar-agama pasca konflik mengandung dua kelemahan yakni struktur yang inklusif yang akan mendorong keterlibatan kalangan non-akademis dan non-agawawan dalam dialog teologis, dan struktur yang koheren dalam upaya dialog antar-agama. Kedua, konsep zona perdamaian sangat terbatas khususnya disebabkan oleh ketergantungan pada syaratsyarat material dalam memuluskan jalan rekonsiliasi menju perdamaian. Ketiga, sifat elitis dan sulit dipahami dari dialog antar-agama pasca konflik serta syarat-syarat material zona perdamaian dapat diperluas dengan mengkolaborasikan dua hal ke dalam zona perdamaian antar-agama yang dapat diterapkan. Terakhir, tulisan ini mengambil studi kasus dialog antar-agama di Desa Latta, Maluku untuk menunjukkan konteks praktis bagi perdamaian antar-agama.
\end{abstract}


Kata-kata kunci: dialog antar-agama, zona perdamaian, pasca kekerasan antar-agama

\section{Introduction}

The idea of the paper is to introduce a hybrid conception of interreligious dialogue and the 'zone of peace'. For the purpose of the paper, interreligious dialogue is defined as conversations between individuals or communities from different religious traditions, either in the form of textual or practical conversations. While the zone of peace is a concept taken from the field of peace studies of grass-root led peaceful sanctuaries that provide the ground for peaceful practices.

The practices of interreligious dialogue in the post-interreligious conflict environment are either highly polarized without any systematic effort to turn it into an effective peacebuilding mechanism, or are almost non-existent due to the elusive terrain of interreligious conflict that it will be a lot easier when the conflict is not deemed as 'interreligious'. On a different note, the establishment of zone of peace has always been based upon material modalities, such as the interest to have an independent economic capacity or the interest to bring back sociopolitical stability.

I argue that a model of interreligious dialogue that adopts the principles of the concept of zone of peace can be applied effectively on to the context of post-interreligious conflict, especially in areas where the current practices of interreligious dialogue are still very limited to certain elite circles. The combination between principles of interreligious dialogue and the concept of zone of peace will be an attempt to form a more inclusive interreligious dialogue, as well as an attempt to expand the concept of zone of peace into a more value-based, rather than materialbased, modality.

The paper will be divided into three sections, namely, first, the elaboration on what is constituted as 'interreligious dialogue' and how it has been practiced in the context of post-interreligious conflict settings; second, the discussion on the concept of zone of peace and its principles; and third, the explanation on the practice of interreligious dialogue within the framework and by utilizing the principles of the zone of peace. The case of the village of Latta in Ambon-Maluku, Indonesia, will provide a practical context for the third section of the paper.

\section{Interreligious Dialogue in the Post-Interreligious Conflict Settings}

A lot of attention has been given to the conceptual development of interreligious dialogue, its understandings and classification that in turn influenced the practices of interreligious dialogue on the ground. One of 
these classifications is proposed by Johannes van der Ven in his paper, "Religious Values in the Interreligious Dialogue" (van der Ven, 1994). Though the classification is designed for differentiating Christians' responses to Muslims, I argue that for the purpose of this paper, the classification is sufficient for explaining broad differences in the way religious believers see each other.

In general, van der Ven (1994: 247) divided the type of responses religious believers have to each other in three broad categories, they are, the monoreligious, multireligious, and interreligious models. In the monoreligious model, religious believers see other religions through certain inclusivist lens. It is important to mention that the monoreligious position does not suggest that there is one true religion that supercedes all others. It is also important to notice that the term 'inclusivist' in van der Ven's model does not necessarily refer to the 'idealistic' notion of inclusivism where all differences can be transcend and melted into one big lump of homogeneity. What van der Ven (1994: 247) means by 'inclusivism' refers to the predilection of Christians in this camp to respect and acknowledge all doctrines, truths, and sensibilities in other religions through the lens of their own religion, in this case, from Christian's lens toward other religions. The model also relies a lot on the conception of 'anonymous Christians' as coined by Karl Rahner (Rahner, Imhof, Biallowons, 1986).

In this first model of interreligious encounter, van der Ven (1994: 248) also divided the inclusivist position into two, namely, the soft inclusivist's and hard inclusivist's positions. The differences between these two inclusivist positions lies at the claim to salvation for the 'anonymous Christians'. On the one hand, for the soft inclusivists, since the sparks of God's Truth and Light can also be found in other faiths, the 'anonymous Christians' also deserve salvations in the sense of living under God's graces. On the other hand, though the hard inclusivists acknowledge the sparks of God's Truth in other religions, they argue that salvation can only be accessed through the Church and Jesus Christ.

The second model is the multireligious model of interreligious encounter (van der Ven, 1994: 250). In this 'modern-inspired' model, all religious traditions are seen as equal because they have been reduced to ensembles of practices and experiences that can be studied comparatively. The underlying assumption of this model is that interreligious encounter serves as a means to observe and learn about others' religious experiences without necessarily talk about the doctrinal and dogmatic teachings of the 
religions. Or if it does, the doctrinal and dogmatic teachings will be seen as parts of the religio-cultural experiences of the believers.

There are two kind of understandings of the multireligious model. The first is the weak multireligious model, and the second is the strong multireligious model. The weak multireligious model refers to an understanding of different religious traditions as equal in two senses, first is that all of religions refer to the worship of the Absolute, and second is that all religions are expressions of human's yearn for the absolute psychological joy.

The second position is the strong multireligious model where the notion of equality in seeing religious differences turns into religious relativism, or even religious indifferentism (van der Ven, 1994: 250). Religious relativism is the notion that individual's affinity to certain religions is dependent on their cultural contexts, for example, somebody is a Muslim because he was born in Saudi Arabia. At the end of the extreme, religious indifferentism will lead to agnosticism since believing in religions is seen as something unimportant. Religion, at this stage, is no more than a cultural experience that invoke curiousity.

The third model is the interreligious model. This model comes as the third way for both monoreligious and multireligious models. It attempts to answer religio-centrism in monoreligious model while also provides an alternative to the reductive dispositions of the multireligious model. Echoing van der Ven (1994: 251-252), the monoreligious model gives too much emphasis on the egocentric dimension of religion (the Iperspective), while the multireligious model only focuses on the 'nature' of religions (the it-perspective).

The interreligious model comes from the assumption that any interreligious encounter must involve what is called as 'perspective exchange'. A 'perspective exchange' entails capacities from religious believers to interpret their own religions from theirs and other religious perspectives, and to interpret other religions from their religious perspective and from the respective religious perspective (van der Ven, 1994: 253). In other words, in order to be able to practice the interreligious model, religious believers must be able to develop sensibilities toward, or better yet experience, other religions. Van der Ven's classification is of course very clear-cut, while realities are often not. However, his models can serve as a heuristic device to differentiate diverse interreligious encounters. 
Other important concepts that are highly relevant with the purpose of this paper are the notion of hospitality in interreligious encounter and the non-textual practices of interreligious dialogue. The notion of 'virtue of hospitality' in the hermeneutics of interreligious dialogue coined by Marianne Moyaert in her 2010 essay, "Absorption or Hospitality: Two Approaches to the Tension Between Identity and Alternity". In her essay, Moyaert (2010: 61) differentiated modes of absorption and hospitality in the light of the problem of preserving the particularities of religious identity when one has an interreligious encounter. The hospitality hermeneutics frames interreligious encounter into a host-guest scenario where 'the identity' meets 'the alter' without having to put their differences away for the sake of finding, or forging, similarities (Moyaert, 2010: 83). In other words, the virtue of hospitality provide a more genuine method of interreligious dialogue in the sense that it encourages participants of the dialogue to accept their dialogue partners with all their differences.

While the concept of non-textual practices in interreligious dialogue is the result of a critical move from the deadlock in the textual understanding of interreligious hermeneutics rooted in the dilemma of how to treat religious particularities in the case of interreligious encounter to a non-verbalize understanding of interreligious hermeneutics. The shift requires an alternative mode of interreligious encounter where it will no longer be seen in terms of 'dialogue' or a limited understanding of hermeneutics (Maraldo, 2010: 96). An alternative interreligious encounter puts more emphasis on non-verbal medium of communication. It means that the bodily language and facial expression, and other forms of nonverbal communication, are more important than the conversations that take place between different parties.

The three concepts mentioned above, van der Ven's interreligious model, Moyaert's notion of hospitality, and the shift from textual understanding of interreligious dialogue to a non-textual one, can be effective frames of interreligious dialogue within the framework of the zone of peace. The focuses on experiential dimension of interreligious dialogue brought by van der Ven's model, on the metaphor of host and guess in the notion of hospitality, and on the importance of embodied practices of interreligious dialogue will be substantial additions to the modified model of the zone of peace in the post-religious conflict settings.

\section{The Zone of Peace}


The concept of zone of peace has been around for sometimes. There are even arguments made for the ancient origin of this concept (Mitchell, Nan, 1997; Langley, 1997; Boulding in Afkhami, 2002: 12-13). In the contemporary context, peace zones are commonly known as designated non-conflictual areas in the middle of conflict zones. The concept itself is more famous in the fields of international relations or security studies, rather than in the field of peace studies. However, there are big differences between the peace zones in IR and the zones of peace in peace studies perspective.

First, the peace zones in international relations are usually established militarily in order to open a safe space for refugees, DDR process, or to channel food aid. The peace zones in peace studies perspective are established through societal consensus to aim for a more sustainable peace. Second, the international peace zones are organized through top-down approach with external international actors or national governments leading the way, while the zones of peace are organized locally, bottom-up, and led by community's initiative. Thirdly, the international peace zones, since it has pretty tangible goals, operated during fairly limited periods, while the local peace zones do not necessarily have time-limitations. In fact, the longer a peace zone could operate, the more successful it is.

The local peace zones are usually organized in three different times during a conflict cycle. First, it can be organized when the conflict occurs to provide protection to the vulnerable groups as well as to initiate the reconciliation process. Second, it can be started right after the conflict ceased to help with the reconciliation process. Lastly, it can be held in the post-conflict settings to generate a culture of peace (Hancock, Iyer, in Hancock and Mitchell, 2007: 30).

The idea behind a local peace zone is that in the time of conflict, a community agreed to make certain territorial areas to be peaceful areas. This commitment is held and keep together by the community, and every outsider who come into the territory must follow the rules applied in the territory. Another important thing is the logic behind a peace zone. In peace studies, a peace zone is established as a site where certain norms, attitudes, and behavior are encouraged and other kind of norms, attitudes, and behavior are discouraged (Mitchell, Nan, 1997: 160). In other words, peace zone is a space for a new type of sociability that is in opposition to the current violent sociability. 
There are, at least, six characteristics that define a zone of peace. First, territoriality, which means that a peace zone is a geographical area within which war and any other forms of armed hostility may no longer be waged, and where peacebuilding programs will address roots and manifestations of conflict in the community; second, grass-root led initiatives, it means that a peace zone is declared by an agglomeration of groups and concerned citizens in the community which organizes itself as a constituency for the peacebuilding agenda; third, long-term commitment where a peace zone is declared and sustained by citizens with a firm conviction rejecting war and upholding peacebuilding as the most desirable option for enhancing human and civil rights and recreating a more humane social order; fourth, proactive participation in which a peace zone's citizens identify the manifestations of violence in their community, which are then the targets of peacebuilding actions within the zone; fifth, local sustainability, it means that a peace zone is reinforced by the community's sustained, creative expressions of commitment to peacebuilding; and sixth, inclusive membership expressed by multisectoral involvement, that is, they combine citizens from and with a variety of local peoples' organizations and supra-local organizations (Avruch, Jose, in Hancock and Mitchell, 2007: 51-52).

While can be considered as a significant progress in the field of peace studies, the conception of local peace zones has its own limitations. One of its biggest limitations is that local peace zones have always been established based on certain material goals, instead of normative ones. Though it is defined very normatively, e.g., to be the place for culture of peace to grow, it is very materialistic in practice. Several famous best practices of local peace zones, such as, the ones in Philippines and El Salvador, were born out of social frustration due to limited economic access. Even the ones that are established in post-conflict settings with religious element in it, such as the case of peace zone in Northern Ireland, are organized to fulfill society's material needs instead of to reach more normative goals.

This discrepancy between ideal and practice is not new in a field as elusive as peace studies. However, the absence of value-based peace zones represents more than just a discrepancy. To some extent, it reflects the disposition of liberal peace paradigm that peace can only be achieved when the human basic needs are fulfilled. It somehow reduces the importance of ideologies, values, and individual experiences into economical needs, access to infrastructure, or competition for strategic 
positions. It is not my position to say that these peace zones have failed in fulfilling their purposes. Rather I argue that there is need and possibility to establish an alternative mode of peace zone based on values, and that this kind of peace zones will be an effective method of conflict transformation in post-religious conflict settings.

\section{Peace Zone for Interreligious Dialogue: A Proposal}

Inspired by one of the few religiously-mixed villages in post-1999 interreligious conflict setting in Ambon, Maluku, Indonesia, I argue for the need to combine the principles of interreligious dialogue and the concept of peace zones. It is my position to say that value-based conflicts, in opposition to interest-based conflicts, need value-based conflict transformation methods in order to achieve sustainable peace. It is also my contention that, first, interreligious dialogue needs to be 'owned' by communities at the grass-root level, and second, that the concept of peace zone needs to be expanded to include value-based modalities.

Against those background, and with the village of Latta in mind, I argue that a peace-zone with embodied interreligious practice is possible to organize. Latta is a village in Ambon in which Christian majority and Muslim minority live side by side despite other religiously-segregated neighborhoods around it. Latta is approximately 45 minutes away from downtown Ambon. During the 1999 conflict, Latta and another religiously-mix neighborhood, Rumah Tiga, were two of the worst hotspots of the conflict. However, the Muslims of Latta, despite the fact that they lived surrounded by the majority Christians, were the first group of refugees who got back to their village. Up to today the Muslims of Latta are considered exemplary due to the harmony they build with the majority Christians.

From my observation in Latta during my two months fieldwork, it is apparent that the Muslim and Christian communities there have established some implicit social norms that regulate their daily lives. These norms, such as, dogs must be restrained and not let to wander around the neighborhood, or quiet hours during weekly mass at the local church, are the products of consensus and trust-building process that has been going on for a while between those two communities (Imam of Latta's mosque, interview by author, tape recording, Ambon, July 18, 
2014). In other words, the village of Latta has established their own religiously-based peace zone though they do not call it so.

The process of interreligious dialogue in Latta does not come as a deliberate action taken by certain groups of people. Rather, it has been a part of their daily lives. It can be said that both the Christian and Muslim communities in Latta are normativized interreligious dialogue, embodied it, and adopted it as a part of their lives. No one in the village really talk about doctrinal teachings except for the religious leaders from both Christian and Muslim communities, though religious traditions are continuously reformed and reshaped by their daily practices. Latta is what Maraldo called as a non-textual practice of interreligious dialogue.

The Muslims and Christians of Latta are also diverse. To live in a religiously-mixed neighborhood does not make them to be homogenous communities up for the multireligious model of interreligious encounter. Nor do they attempt to find similarities for the sake of bridging dialogue between them. Each community holds their traditions dearly, not to mention that some of the individuals in Latta were actually pretty conservative, in the sense that they are yet to be able to engage in interreligious model as prescribed by van der Ven. To explain the kind of 'living' interreligious dialogue that the communities of Latta do, I think it is best for us to return to the notion of hospitality in interreligious dialogue proposed by Moyaert. The practice of interreligious dialogue in Latta is best described by the host and guess metaphor that Moyaert mentioned. Everyone in Latta is either a 'guest' or a 'host' for everyone elses. Muslims and Christians are constantly reshaping and redefining their relationships to each other based on new insights they get from their everyday interactions. These interactions, in turn, not necessarily change whatever beliefs and doctrines that they hold on to. In other words, they are merely 'guest', or 'host', to each other. They accept their neighbor's 'visits', while maintaining their positions as a 'host', or as a 'guest'.

Of course this ongoing trust-building and dialogic processes is not without its obstacles. Debates centered around doctrinal teachings freshly proposed by clerics or pastors are dominating the picture at times. However, when I asked a group of Muslim mothers of Latta on whether or not they would like to move to 'Muslim-only villages', the answer is no (Muslim mothers of Latta, interview by author, tape recording, Ambon, July 19, 2014). The peaceful interreligious living in Latta is treasured by every single resident of the village. For them, Latta is home. 
The principles of interreligious dialogue will give fresh insights on how we organized a peace zone. While the zone of peace model would serve as an effective organizational method when it comes to practicing interreligious dialogue at the grassroot level. On the one hand, the principles of interreligious dialogue open a possibility for us to expand the material-based peace zone into a value-based peace zone. On the other hand, the peace zone model can serve as a practical form of interreligious dialogue, which then hopefully, can be owned by individuals at the grassroot level.

\section{Conclusion}

Materialistic motives, such as, economic and political interests, are indeed such contributing factors to the occurence of conflict. However, conflicts are also multi-faceted, and we cannot erase intangible motives, such as, religion, from the equation simply because they are not obvious. In the context of post-interreligious violence, the needs to acknowledge the more abstract dimensions of conflict is even more explicit. Various attempts on interreligious dialogue in post-conflict settings have been largely limited to certain elitist circles consist of scholars and clergies without involving the grass-root element of the society. Meanwhile, they are the ones who are most likely to be participated and become the victims of the conflict. Claim that is usually made to justify an elitist practice of interreligious dialogue is that the dialogue should occupy the realm of theology in order to understand other religious traditions in a more genuine manner. While this claim is valid to some extent, we cannot rely on interreligious dialogue at the level of theology in order to make peace between the communities. The article offered three alternative models of interreligious dialogue (van der Ven's interreligious model, Moyaert's notion of hospitality, and Maraldo's shift from verbal to non-verbal model of interreligious dialogue) that are centered around the embodied experience of interreligious dialogue rather than on a dialogue that is more academic, and thus elitist, in nature. These models reflected the practice of interreligious dialogue at the grass-root level that are much more inclusive than the elitist circles model.

But then a problem remains, how to consolidate the current state of sporadic efforts of interreligious dialogue? This is where the concept of zone of peace comes. As a targeted, purpose-driven mechanism in building peace, zone of peace is a very effective means to pave the way to reconciliation after an outbreak of violence. However, the application of 
the zone of peace has been very limited to providing basic material bonds between the conflicting parties. That being said, if a conflict lack of material motives in the first place, it would be very hard to establish the structure of the zone of peace on the respective context. Thus, collaboration between the experiential notion of interreligious dialogue within the framework of zone of peace is offered in order to, first, gain the effectitivity of the framework of zone of peace, and second, take into account an alternative model of interreligious encounter that is not relying merely on theological exchange to conduct a dialogue. Furthermore, the interreligious encounter that takes place in the village of Latta in Maluku served as a living example of the experiential mode of interreligious dialogue within a concept of zone of peace. In Latta, everyday dialogue is weaved within a deep sense of mutual understanding for each other, which in turn becomes a key to establish the effective interreligious zone of peace. After all, peacebuilding is a matter of the people, not the government's, nor the clergies's.

\section{Bibliography}

Mitchell, C., Nan, S. A. (1997). Local Peace Zones as Institutionalized Conflict. Peace Review, 9(2), pp. 159-162.

Boulding, E. (2002). Peace Culture. In: Afkhami, M. ed. Toward A Compassionate Society. Women's Learning Partnership for Rights, Development, and Peace, pp. 8-15.

van der Ven, J. (1994). Religious Values in the Interreligious Dialogue. Religion and Theology, 1(3), pp. 244-260.

Maraldo, J. C. (2010). A Call for an Alternative Notion of Understanding in Interreligious Hermeneutics. In: Cornille, C. \& Conway, C. Interreligious Hermeneutics. Cascade Books, pp. 89-115.

Rahner, K., Imhof, P., Biallowons, H. (1986). Karl Rahner in Dialogue: Conversations and Interviews, 1965-1982. Crossroad Publishing.

Avruch, K., Jose, R. S. (2007). Peace Zones in the Philippines. In: Hancock, L. E. \& Mitchell, C. eds. Zones of Peace. Kumarian Press, pp. 51-69.

Hancock, L. E., Iyer, P. (2007). The Nature, Structure, and Variety of Peace Zones. In: Hancock, L. E. \& Mitchell, C. eds. Zones of Peace. Kumarian Press, pp. 2950 .

Moyaert, M. (2010). Absorption or Hospitality: Two Approaches to the Tension Between Identity and Alterity. In: Cornille, C. \& Conway, C. eds. Interreligious Hermeneutics. Cascade Books, pp. 61-88.

Langley, W. E. (1997). Children, a Global Ethic, and Zones of Peace. Peace Review, 9(2), pp. 183-188. 
Indonesian Perspective, Vol 1 No. 1 (Januari-Juni): 63-73 
Fitriyah: Religions in Times of Peace 